\title{
$\begin{array}{ll}\text { Research Square } & \text { Preprints are preliminary reports that have not undergone peer review. } \\ \text { They should not be considered conclusive, used to inform clinical practice, }\end{array}$
}

\section{An In-vitro evaluation of a polyherbal formulation, against SARS-CoV-2}

Divya Kanchibhotla ( $\sim$ operations@ssiar.org )

Sri Sri Institute for Advanced Research https://orcid.org/0000-0002-0760-630X

\section{Saumya Subramanian}

Sri Sri Institute for Advanced Research https://orcid.org/0000-0001-9215-3933

\section{Dr Ravi Reddy}

Sriveda Sattva Pvt. Ltd https://orcid.org/0000-0002-8582-9656

Dr. Hari Venkatesh K.R.

Sriveda Sattva Pvt. Ltd https://orcid.org/0000-0003-1176-3831

Dr. Monika Pathania

All India Institute for Medical Science, Rishikesh

\section{Research Article}

Keywords: Polyherbal, Ayurvedic, COVID-19, SARS-CoV-2, in-vitro, NOQ19

Posted Date: September 28th, 2021

DOI: https://doi.org/10.21203/rs.3.rs-936472/v1

License: @ (i) This work is licensed under a Creative Commons Attribution 4.0 International License. Read Full License 


\section{Abstract}

Background: COVID-19, caused by SARS-CoV-2 is one of the major health crisis that has affected the world in the past century. With the emergence of new strains of viruses and antimicrobial resistance, the world is looking for an alternate therapeutic option to fight infectious disease.

Objective: The present study evaluated the efficacy of a novel polyherbal formulation, named NOQ19, against SARS-CoV-2 in an in vitro setting. NOQ 19 is an unique blend of 13 Ayurvedic herbs.

Methodology: Vero E6 (CL1008), the African green monkey kidney epithelial cell, were infected with SARS-CoV-2 virus (isolate USA-WA1/2020) in a 96 well-plate. NOQ19 test material was diluted in different concentration as follows $0.05 \mathrm{mg} / \mathrm{ml}, 0.1 \mathrm{mg} / \mathrm{ml}, 0.2 \mathrm{mg} / \mathrm{ml}, 0.3 \mathrm{mg} / \mathrm{ml}, 0.4 \mathrm{mg} / \mathrm{ml}, 0.5 \mathrm{mg} / \mathrm{ml}, 0.6 \mathrm{mg} / \mathrm{ml}, 0.7 \mathrm{mg} / \mathrm{ml}, 0.8 \mathrm{mg} / \mathrm{ml}$ and $0.9 \mathrm{mg} / \mathrm{ml}$. These different concentrations of NOQ19 were added to infected cells respectively and incubated for 3 days in $5 \%$ CO2 incubator. Remdesivir was used as a positive control.The cells were finally fixed with formaldehyde, stained with crystal violet and plaques were visualized. The number of plaques were counted to determine the PFU(plaque forming units)/mL.

Results: Results demonstrated $100 \%$ antiviral efficacy of NOQ19 at $0.9 \mathrm{mg} / \mathrm{ml}$ concentration with complete elimination of the virus. The IC50 of the drug was found to be $0.2 \mathrm{mg} / \mathrm{ml}$. The results of the present study demonstrated viral load reduction in SARS- CoV-2 infected Vero E6 cell lines.

Conclusion: The result along with clinical trials could propose NOQ19 as a potential therapeutic option in the fighting the COVID-19 challenge.

\subsection{Introduction}

SARS-CoV-2 is the causal agent of the COVD-19 pandemic. Coronaviruses are zoonotic in nature and their cross over to humans has led to multiple epidemics and a pandemic. Betacoronavirus from the Coronaviridea family are a single stranded positive sense RNA virus with spike like projections which cause respiratory infections.1 Before the pandemic, NL63, OC43, 229E and HKU1 were among the common strains of coronavirus infecting humans. ${ }^{[1]}$ Past decade has seen the emergence of three new strains of coronavirus namely SARS CoV, MERS CoV and SARS-CoV-2 with increasing morbidity and mortality. ${ }^{[2]}$ Wuhan, China reported cases of acute respiratory distress in late 2019, precursors to the outbreak of COVID-19. [3] Pharmaceutical companies all across the globe are in search of an effective antiviral treatment against the virus. Unfortunately, no drugs or monoclonal antibodies are approved for treatment of SARS-CoV-2 infection. The health care industry across the world have started to "repurpose" several already approved antivirals. Among those Remdesivir, a well-known antiviral drug against RNA viruses, has been extensively used in COVID-19 patients. ${ }^{[4]}$ However, a major drawback of repurposing antivirals includes lack of therapeutic cure, side effects, insufficient studies on dosage and emergence of mutated strains. ${ }^{[5]}$

The nature has provided humanity with a huge array of phytochemicals and other compounds which have been minimally explored in the context of COVID-19 treatment. Some of these compounds may exhibit good antiviral properties due to the presence of alkaloids, flavanoids, tannins and phenols. ${ }^{[6]}$ The present study focuses on a novel Ayurvedic formulation, NOQ19 which contains 13 potent herbs. The drug includes herbs such as Ashwagandha (Withania somnifera), Bilwa (Aegle marmelos), Yashtimadhu (Glycyrrhiza glabra), Rasna (Pluchea lanceolata), Vasaka (Adhatoda vasica), Pippali (Piper longum), Haridra (Curcuma longa), Patha (Cissampelos pareira), Bhumiamla (Phyllanthus fraternus), Bhunimba (Andrographis paniculata), Saptaparna (Alstonia scholaris), Tulasi (Ocimum sanctum) and Guduci (Tinospora cordifolia) powder and extract. Some of these herbs are routinely consumed in India, the land of origin of Ayurveda, for their taste and health benefits. Due to their high antimicrobial activity, these herbs also act as a food preservative. ${ }^{[7]}$ Through an in silico study, four potential constituents of Ashwagandha (Withanoside II, Withanoside IV, Withanoside V and Sitoindoside IX) 
have shown the highest docking ability with SARS-CoV-2 viral target protein $\mathrm{M}^{\text {pro }}$ among Ashwagandha components, thus inibhiting its activity. $\mathrm{M}^{\text {pro }}$ protease enzyme is essential for viral propagation and replication of SARS-CoV-2. ${ }^{\left[{ }^{8]}\right.}$ Another study demonstrated that Withanolides had the highest drug likeliness score and a positive human intestinal absorption in a molecular docking study. ${ }^{[9]}$ Yashtimadhu, another component of NOQ19 exhibits an excellent antiviral activity. A study from Frankfurt showed that, among the various components from Yashtimadhu, tested against SARS-CoV virus viral replication, glycyrrhizin, a component of Yashtimadhu, had the best viral replication inhibiting property. ${ }^{[10]}$ Another animal study highlighted the role of glycyrrhizin in reducing the number of Angiotensin converting enzyme 2 (ACE2) receptors in the lung tissues. ACE2 is essential for SARS-CoV-2 binding and causing COVID-19. This activity is achieved by inhibiting 11 beta hydroxysteroid dehydrogenase type 2 (11 betaHSD2) and activating mineralocorticoid receptor (MR). In intestinial cells, the co-expression of these three enzyme results in a reduction of ACE2 expression. ${ }^{[11]} \mathrm{A}$ molecular docking study revealed that tinocordiside, a component of Giloy docked well with ACE2-RBD complex, making the host cell ACE2 receptor unavailable for SARS-CoV-2 spike protein. ${ }^{[12]}$ Another combined simulation study focused on the active phytochemicals from Ashwagandha, Bhumiamla, Giloy and Amla against a potiental target $\mathrm{M}^{\text {pro }}$ of SARS-CoV-2. The study revealed that Amritoside and Apigenin-6-C-glucosyl7-O-glucoside from Giloy, and Pectolinarin and Astragalin from Bhumiamla showed the best affinity to COVID-19 M ${ }^{\text {pro }[13]}$ Other ingredient of NOQ19 Bhunimba (Andrographis paniculata), prevents blood clotting because of its antithrombotic property. ${ }^{[14]}$ Haridra is a routinely used spice in India known for is antimicrobial properties. It can also modulate the cytokine release and therefore helps in clinical improvement of patients most viral infection. ${ }^{[15]}$

Objective: The compounds used in the novel Ayurvedic formulation NOQ19 exhibit good anti-viral properties against SARSCoV-2 as noted in many simulated studies. The present study evaluates antiviral activity of the formulation (NOQ19) against SARS-CoV-2 in a Vero E6 cell line in an in vitro setting as further exploration of the antiviral activity of NOQ19.

\subsection{Methodology}

2.1 NOQ19 preparation: NOQ19 contains a combination of Ashwagandha (Withania somnifera), Bilwa (Aegle marmelos), Yashtimadhu (Glycyrrhiza glabra), Rasna (Pluchea lanceolata), Vasaka (Adhatoda vasica), Pippali (Piper longum), Tamalaki (Phyllanthus fraternus), Kalamegha/ Kiratatikta (Andrographis paniculata), Saptaparna (Alstonia scholaris), Haridra (Curcuma longa), Patha (Cissampelos pareira) herbs.

NOQ 19 was procured from Sriveda Sattva Pvt Ltd, Bangalore (Sri Sri Tattva). The drug was licensed by Ministry of AYUSH, Govt. of India with the license number- AUS782. It was supplied in the powdered form and stored at $4^{\circ} \mathrm{C}$ until further use.

All the herbs \& herbal extracts which constituted NOQ19 were subjected for Quality control Analysis and after approval process, ingredients were issued for production as fine powders. All the ingredients were blended with excipients followed by granulation and drying.

2.2 Cell culture: Vero E6 (CL1008), the African green monkey kidney epithelial cell line was obtained from Elabscience Biotechnology Inc. (Cat no. EP-CL-0491) and cultured in DMEM supplemented with $10 \%$ FBS and antibiotic antimycotic solutions at $37^{\circ} \mathrm{C}$ in a humidified $\mathrm{CO} 2(5 \%)$ incubator.

2.3 Virus cells: The SARS-CoV-2 viral isolate was obtained by BEI resources managed by ATCC. Isolate USA-WA1/2020 was isolated from an oropharyngeal swab from a patient with a respiratory illness who had recently returned from travel to the affected region of China and developed clinical disease (COVID-19) in January 2020 in Washington, USA. ${ }^{\text {[16] }}$

2.4 Test Material preparation: A stock solution of the NOQ19 powder was dissolved in DMSO and was made to 100X concentration. The NOQ19 was manufactured by Sriveda Sattva Pvt Ltd, Bangalore (Sri Sri Tattva). The stock solution was serially diluted at $1 / 20$ with Phosphate Buffer saline (PBS) to obtain $5 \mathrm{X}$ solution, used for the assay. $100 \mu$ l of this solution 
was added in all the wells. $100 \mu$ l of PBS was added to the positive cell control well, while $100 \mu$ l of remdesivir solution was added to the positive test control.

\subsection{Plaque reduction assay.}

The assay plate was coated with $200 \mu \mathrm{L}$ of 30,000 (approx.) Vero E6 cells in a media of DMEM containing $10 \%$ FBS per well. A 96 well-plate was used for the assay. The plates were incubated overnight $(12-18 \mathrm{~h})$ at $37^{\circ} \mathrm{C}$.

Three plates were used for controls as following: a) positive control (virus infected cells with remdesivir), b) virus only control (Vero E6 cells infected with virus without any drug), c) cell only control (Vero E6 cells without the infection or any drug). After overnight incubation, the excess of cell culture media was removed and $100 \mu$ l of test material diluted to required concentrations was added. The following concentrations were used for NOQ19: $0.05,0.1,0.2,0.3,0.4,0.5,0.6,0.7$, $0.8,0.9,1 \mathrm{mg} / \mathrm{ml}$ (Table 1).

The test was performed in duplicates to nullify any error. After loading of the test material, the plates were incubated in a $5 \% \mathrm{CO}_{2}$ incubator for an hour. After $1 \mathrm{~h}$ of pre-incubation with the test material, the test material was removed and $30 \mu \mathrm{L} /$ well of a virus mix (prepared in infection medium) was added. The virus mix contained virus at multiplicity of Infection, (MOI) of 0.01 . After virus was added, the plates were again incubated at $37^{\circ} \mathrm{C}$ in $\mathrm{CO}_{2}$ incubator $(5 \%)$ for $1 \mathrm{~h}$ with shaking 15 minutes intervals. After $1 \mathrm{~h}$, the medium containing the test material and the virus were removed from the wells. Thereafter, $200 \mu \mathrm{L}$ of DMEM: Carboxymethylcellouse (CMC) mixture, containing the test material at desired concentration, was added to each well of the 96 -well plates. The infected cell lines were incubated at the $37^{\circ} \mathrm{C}, 5 \% \mathrm{CO}_{2}$ for 3 days. After 3 days of incubation, the CMC overlay was removed gently with a pipette and the cells were washed twice with PBS buffer. The cells were fixed with $200 \mu \mathrm{L}$ of $4 \%$ formaldehyde added to each well and incubated for 30 minutes. Formaldehyde was removed and $100 \mu \mathrm{L}$ of $0.05 \%$ (w/v) crystal violet in $20 \%$ methanol was added to each well and incubated for 20-30 minutes. After 30 minutes, the excess crystal violet was removed with distilled water and plaques were visualized. The number of plaques were counted to determine the $\mathrm{PFU} / \mathrm{mL}$, the log reduction and percentage viral load reduction in the presence of test material. The IC-50 of the test material was determined using GraphPad Prism software (Version 9.0.1)

The experiment was conducted at Foundation for Neglected Disease Research (FNDR). FNDR's research and handling of SARS-CoV-2 has been endorsed by its Institutional Biosafety Committee. All SARS-CoV-2 studies were performed with approved standard operating procedures and conform to the safety requirements recommended by the Department of Biotechnology, Government of India. 
Table 1

Different concentration gradient of NOQ19

used for the assay

\begin{tabular}{|c|c|c|}
\hline S.NO & Test Material & Concentration \\
\hline 1 & \multirow[t]{11}{*}{ NF2 } & $1 \mathrm{mg} / \mathrm{ml}$ \\
\hline 2 & & $0.9 \mathrm{mg} / \mathrm{ml}$ \\
\hline 3 & & $0.8 \mathrm{mg} / \mathrm{ml}$ \\
\hline 4 & & $0.7 \mathrm{mg} / \mathrm{ml}$ \\
\hline 5 & & $0.6 \mathrm{mg} / \mathrm{ml}$ \\
\hline 6 & & $0.5 \mathrm{mg} / \mathrm{ml}$ \\
\hline 7 & & $0.4 \mathrm{mg} / \mathrm{ml}$ \\
\hline 8 & & $0.3 \mathrm{mg} / \mathrm{ml}$ \\
\hline 9 & & $0.2 \mathrm{mg} / \mathrm{ml}$ \\
\hline 10 & & $0.1 \mathrm{mg} / \mathrm{ml}$ \\
\hline 100 & & $0.05 \mathrm{mg} / \mathrm{ml}$ \\
\hline
\end{tabular}

\subsection{Results}

Plaque Assay Data table (Table 2) represents the various concentrations of test material NOQ19 and positive control remdesivir and corresponding plaque forming units at different concentrations. The test was run in duplicates and the average plaque forming units were calculated.

\subsection{Test Material}

The test material (NF2) NOQ19 was found to exhibit antiviral activity against SARS-CoV-2. The highest antiviral activity noted was $100 \%$ viral load reduction at a concentration of $0.9 \mathrm{mg} / \mathrm{ml}$. (Table 2). At this concentration, NOQ19 was found to nullify the virus completely. The IC-50 was calculated by considering the top value of 100 and baseline value of 0 and was found to be $0.2 \mathrm{mg} / \mathrm{mL}$ (Fig. 1).

\subsection{Control}

The IC-50 value of positive control (Remdesivir) was calculated by considering the top value of 100 and baseline value 0 . (Table 2) The reported IC-50 was $1.3 \mu \mathrm{M}$.(Fig. 2). The test results correlated to internal report and various literature. ${ }^{[17,18]}$ The test and negative controls ensured the efficacy of viral isolates, cell lines used and the test procedure. By providing respective controls, it was ensured that the antiviral effects in test material arm were caused only due to the antiviral efficacy of NOQ19 and not due to any toxicity. 
Table 2

Viral load reduction among different concentrations of NOQ19

\begin{tabular}{|c|c|c|c|c|c|c|c|c|c|c|}
\hline \multirow{2}{*}{$\begin{array}{l}\text { Sl. } \\
\text { No. }\end{array}$} & \multirow[t]{2}{*}{ Sample } & \multirow[t]{2}{*}{ Concentration } & \multicolumn{3}{|c|}{ No. of Plaques } & \multirow{2}{*}{$\begin{array}{l}\text { Dilution } \\
\text { Factor }\end{array}$} & \multirow[t]{2}{*}{ PFU/ ml } & \multirow{2}{*}{$\begin{array}{l}\text { Log } \\
\text { PFU/ } \\
\text { ml }\end{array}$} & \multirow{2}{*}{$\begin{array}{l}\text { Log } \\
\text { reductions } \\
\text { of virus } \\
\text { load }\end{array}$} & \multirow{2}{*}{$\begin{array}{l}\text { Percentage } \\
\text { Reduction } \\
\text { of virus } \\
\text { load (\%) }\end{array}$} \\
\hline & & & 1 & 2 & Average & & & & & \\
\hline 1 & $\begin{array}{l}\text { Virus only } \\
\text { control }\end{array}$ & & 22 & 19 & 20.5 & 1000 & $6,83,333$ & 5.83 & & \\
\hline 2 & Cell only & & 0 & 0 & 0 & NA & NA & NA & NA & NA \\
\hline \multirow[t]{2}{*}{3} & Remdesivir & $25 u M$ & 0 & 0 & 0 & 1000 & 0 & & NA & 100.00 \\
\hline & $\begin{array}{l}\text { (Positive } \\
\text { control) }\end{array}$ & $12.5 \mathrm{uM}$ & 0 & 0 & 0 & 1000 & 0 & & NA & 100.00 \\
\hline \multirow[t]{8}{*}{4} & NF2 & $1 \mathrm{mg} / \mathrm{ml}$ & Cytc & oxic & & 1000 & NA & NA & NA & NA \\
\hline & & $0.9 \mathrm{mg} / \mathrm{ml}$ & 0 & 0 & 0 & 1000 & 0 & & NA & 100.00 \\
\hline & & $0.8 \mathrm{mg} / \mathrm{ml}$ & 2 & 1 & 1.5 & 1000 & 50,000 & 4.7 & 1.14 & 92.68 \\
\hline & & $0.7 \mathrm{mg} / \mathrm{ml}$ & 3 & 3 & 3 & 1000 & 100000 & 5 & 0.83 & 85.37 \\
\hline & & $0.6 \mathrm{mg} / \mathrm{ml}$ & 3 & 4 & 3.5 & 1000 & 166667 & 5.07 & 0.77 & 82.93 \\
\hline & & $0.5 \mathrm{mg} / \mathrm{ml}$ & 4 & 6 & 5 & 1000 & 166667 & 5.22 & 0.61 & 75.61 \\
\hline & & $0.4 \mathrm{mg} / \mathrm{ml}$ & 5 & 8 & 6.5 & 1000 & 266667 & 5.34 & 0.50 & 68.29 \\
\hline & & $0.3 \mathrm{mg} / \mathrm{ml}$ & 10 & 8 & 9 & 1000 & 300000 & 5.48 & 0.36 & 56.10 \\
\hline
\end{tabular}

\subsection{Discussion}

Natural herbs and extracts have been used since centuries in India to cure different ailments. Although synthetic medicines are popular and widely used, health care professionals are once again appreciating the benefits of herbal medicine due to number of issues that use of synthetic medicines create. The side effects, emergence of antimicrobial resistance and cost are few disadvantages of synthetic medicines. ${ }^{[19]}$ The current pandemic, emergence of 'black fungus' and lack of substantial cure for COVID-19 has led to questions regarding the efficiency of the pharmaceuticals in curing the population during such outbreaks. The present study evaluated the antiviral efficacy of a novel formulation NOQ19 composed of wellknown medicinal herbs. This is the first study to test the invitro efficacy of the newly formulated drug NOQ19. The drug showed a $100 \%$ reduction in the viral load of SARS-CoV-2 at $0.9 \mathrm{mg} / \mathrm{ml}$. A similar in-vitro study on one of the other popular herbal siddha formulation, Kabasura Kudineer demonstrated a significant reduction, by $99.5 \%$, in the viral replication of SARS-CoV-2 after 48 hours, therefore inhibiting the further progression of the disease. ${ }^{[20]}$ It is important to note that KSK has compounds similar to NOQ19 such as Ashwagandha, Haridra and Yashtimadhu. Also, another in-vitro study on Ashwagandha showed its potiential benefit in reduction of HCV virus. The viral load reduction as measured by PCR was noted as $6.241 \times 103 \mathrm{lU} / \mathrm{mL}$ at $25 \mathrm{mg} / \mathrm{ml}$ concentration. ${ }^{[21]}$ A study on Glycyrrhizin, a major component of Yashtimadhu, showed that the expression of the viral antigens produced by SARS-CoV was much lower in the cultures treated with 1000 $\mathrm{mg} / \mathrm{L}$ glycyrrhizin, than the other compounds, and at $4000 \mathrm{mg} / \mathrm{ml}$ Glycyrrhizin completely blocked the replication. ${ }^{[22]}$ We assume Withanoside $X$ and Glycyrrhizin to be the chief components of NOQ19, responsible for preventing the viral replication among the SARS-CoV-2 virus. ${ }^{[23,24]}$ However, the current study is only an in vitro evaluation of the drug in a VeroE6 cell line. Along with our results, further clinical trials have to be performed in order to test the safety and efficacy of NOQ19 in humans. 


\subsection{Conclusion}

Nature is abundant with resources that have curative and preventive properties against various harmful organisms. The present study explores a novel Ayurvedic formulation NOQ19 against COVID-19 in a Vero E6 cell based assay. The study highlighted complete elimination of the virus at $0.9 \mathrm{mg} / \mathrm{ml}$ highlighting NOQ19's potential efficacy against COVID-19. The present study along with clinical trial results could pose a beneficial alternate therapeutic solution for the pandemic.

\section{Declarations}

\section{Acknowledgments}

We would like to acknowledge Dr. Rudra Murthy G.R. Foundation for Neglected Disease Research (FNDR), Bengaluru for conducting the experiment in their Bio Safety Lab-3 facility.We would also like to acknowledge Dr Somya Ramrakhyani for language edits.

\section{Conflict of Interest}

The authors have no conflict of interests to declare. All the authors have seen and approved the manuscript.

\section{Funding}

We would like to thank Cooper Family Foundation, Australia for providing us the funding for this in vitro study.

\section{References}

1. Singhal T. A review of coronavirus disease-2019 (COVID-19). Indian J. Pediatr 2020;87:281-6.

2. Perlman S. Another decade, another coronavirus. N Engl J Med 2020;382:760-762.

3. Hussein M, Alsayed R, Hussain Z, Salih N, Yousif E. An Overview of Possible Therapeutic Approaches Against Novel Coronavirus Disease 2019 (COVID-19) Pandemic. ANJS 2020; 16;3(1):6-11.

4. Liang C, Tian L, Liu Y, Hui N, Qiao G, Li H, Shi Z, Tang Y, Zhang D, Xie X, Zhao X. A promising antiviral candidate drug for the COVID-19 pandemic: A mini-review of remdesivir. Eur. J. Med. Chem 2020;201:112527.

5. Parvathaneni V, Gupta V. Utilizing drug repurposing against COVID-19-Efficacy, limitations, and challenges. Life Sci 2020;17:118275.

6. Ben-Shabat S, Yarmolinsky L, Porat D, Dahan A. Antiviral effect of phytochemicals from medicinal plants: Applications and drug delivery strategies. Drug Deliv Transl Res 2020;10(2):354-67.

7. Sachan AK, Kumar S, Kumari K, Singh D. Medicinal uses of spices used in our traditional culture: Worldwide. J Med Plants Stud 2018;6(3):116-22.

8. Tripathi MK, Singh P, Sharma S, Singh TP, Ethayathulla AS, Kaur P. Identification of bioactive molecule from Withania somnifera (Ashwagandha) as SARS-CoV-2 main protease inhibitor. J Biomol Struct Dyn 2020;6:1-4.

9. Khanal P, Chikhale R, Dey YN, Pasha I, Chand S, Gurav N, Ayyanar M, Patil BM, Gurav S. Withanolides from Withania somnifera as an immunity booster and their therapeutic options against COVID-19. J Biomol Struct Dyn 2020;26:1-4.

10. Damle M. Glycyrrhiza glabra (Liquorice)-a potent medicinal herb. Int J Herb Med 2014;2(2):132-6.

11. Jezova D, Karailiev P, Karailievova L, Puhova A, Murck H. Food Enrichment with Glycyrrhiza glabra Extract Suppresses ACE2 mRNA and Protein Expression in Rats-Possible Implications for COVID-19. Nutrients 2021;13, 2321.

12. Balkrishna A, Pokhrel S, Varshney A. Tinospora cordifolia (Giloy) may curb COVID-19 contagion: tinocordiside disrupts the electrostatic interactions between ACE2 and RBD. Authorea Preprints 2020. 
13. Murugesan S, Kottekad S, Crasta I, Sreevathsan S, Usharani D, Perumal MK, Mudliar SN. Targeting COVID-19 (SARSCoV-2) main protease through active phytocompounds of ayurvedic medicinal plants-Emblica officinalis (Amla), Phyllanthus niruri Linn.(Bhumi Amla) and Tinospora cordifolia (Giloy)-A molecular docking and simulation study. Comput. Biol. Med 2021;136:104683.

14. Mishra SK, Sangwan NS, Sangwan RS. Phcog rev.: Plant review Andrographis paniculata (Kalmegh): A review. Pharmacogn Rev 2007;1(2):283-98.

15. Panda AK, Dixit AK, Rout S, Mishra B, Purad UV, Kar S. Ayurveda practitioners consensus to develop strategies for prevention and treatment of Corona Virus Disease (COVID-19). J-AIM 2020;5(1):98-106.

16. BEI resources. https://www.beiresources.org/Catalog/animalviruses/NR-52281.aspx. 8th September, 2021

17. Ko M, Jeon S, Ryu WS, Kim S. Comparative analysis of antiviral efficacy of FDA-approved drugs against SARS-CoV-2 in human lung cells. J Med Virol 2021;93(3):1403-8.

18. Wang M, Cao R, Zhang L, Yang X, Liu J, Xu M, Shi Z, Hu Z, Zhong W, Xiao G. Remdesivir and chloroquine effectively inhibit the recently emerged novel coronavirus (2019-nCoV) in vitro. Cell Res 2020;30(3):269-71.

19. Mosihuzzaman M. Herbal medicine in healthcare-an overview. Nat Prod Commun 2012;7(6):1934578X1200700628.

20. MS SD, Sathiyarajeswaran P, Karthik L, Kanakavalli K, Chandru S, Nipendra Singh. In vitro Antiviral Activity of Kabasura Kudineer-Siddha Polyherbal Formulation Against Novel Coronavirus (SARS-CoV-2). SSRN 2021

21. Mofed D, Ahmed W, Zekri AR, Said O, Rahouma M, Faraag AH. The Antiviral Efficacy of Withania somnifera (Ashwagandha) against Hepatitis C Virus Activity: In Vitro and in Silico Study. Adv Microbiol 2020;10(9):463-77.

22. Cinatl J, Morgenstern B, Bauer G, Chandra P, Rabenau H, Doerr HW. Glycyrrhizin, an active component of liquorice roots, and replication of SARS-associated coronavirus. Lancet 2003;361(9374):2045-6.

23. Chikhale RV, Gurav SS, Patil RB, Sinha SK, Prasad SK, Shakya A, Shrivastava SK, Gurav NS, Prasad RS. SARS-CoV-2 host entry and replication inhibitors from Indian ginseng: an in-silico approach. J Biomol Struct Dyn 2020;20:1-2.

24. Van de Sand L, Bormann M, Alt M, Schipper L, Heilingloh CS, Steinmann E, Todt D, Dittmer U, Elsner C, Witzke O. Glycyrrhizin Effectively Inhibits SARS-CoV-2 Replication by Inhibiting the Viral Main Protease. Viruses 2021; 13:609.

\section{Figures}

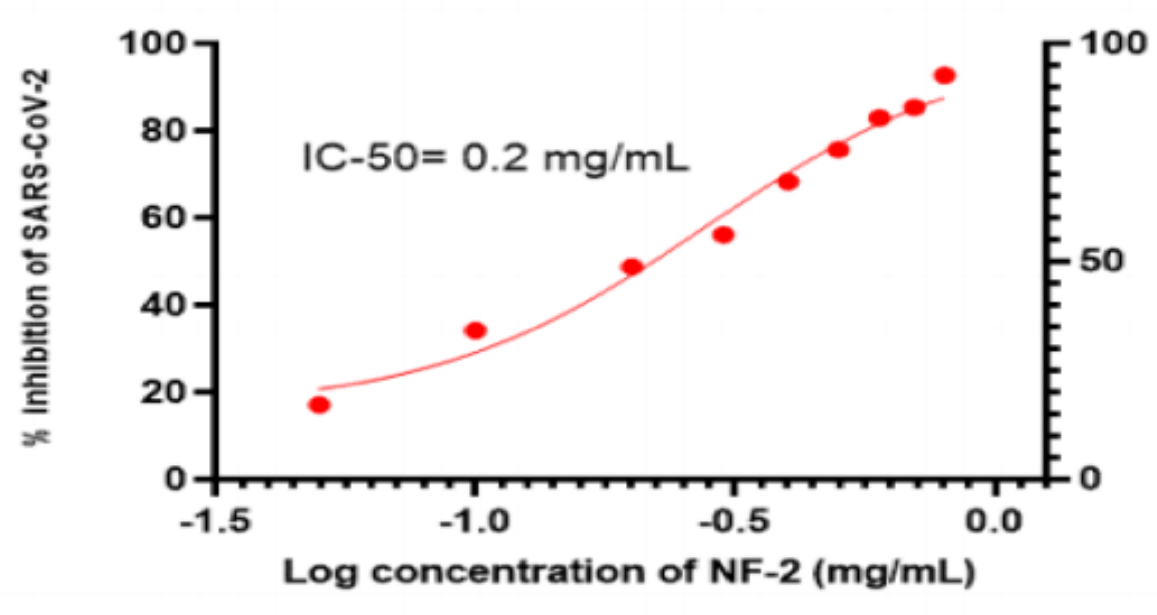

Figure 1

IC-50 efficacy of test material NOQ19 


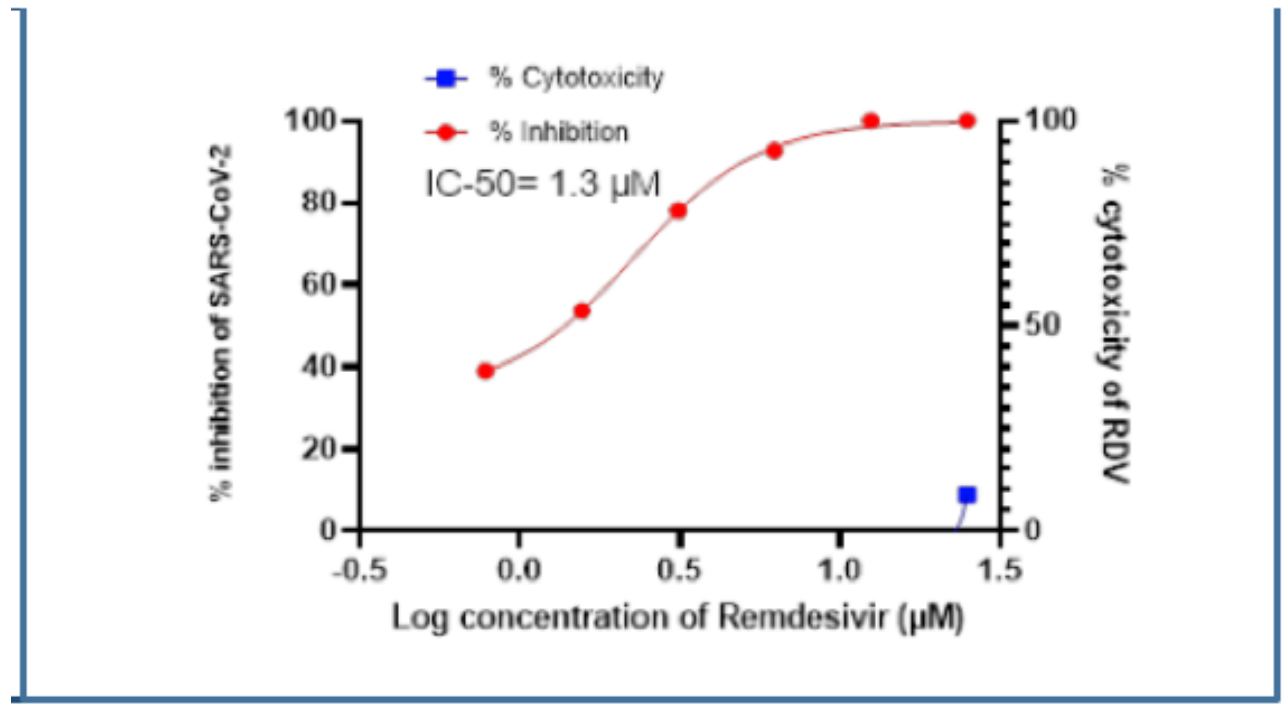

Figure 2

IC-50 efficacy of Remdesivir 